preserve the anatomical details of the wood so well that growthring studies may be carried out on them exactly as if they were modern wood. Although conifers in temperate and sub-alpine zones have been exploited for climatic reconstruction, tropical and subtropical trees, with the exception ofTeak (Tectona grandis), have been seldom tested. This is due to a lack of information on datable tree rings from the Indian subcontinent. Nevertheless, transverse sections of some of the fossil logs look similar to growth rings, although they are yet to be evaluated microscopically (Fig. 2c, d).

Further excavation and meticulous searching of the fossil woods and sub-fossil logs in the wetlands of Kerala may lead to the identification of additional potential species for dendroclimatic study. Although a few taxa have demonstrated the potential for climatic reconstruction of the historical period, no attempt has been made yet to examine the Holocene or recent past based on tree growth-ring studies. In fact, tree-ring studies of tropical forest species have not often been undertaken, though such studies would be of great significance in terms of investigating global climatic change. There is good scope for paleo-dendroclimatological study in India and what has been discovered so far appears to be only the begining.

\section{ACKNOWLedgements}

The authors are grateful to KSCSTE,

Thiruvanantha-puram for granting project No.56/03/KSCSTE. KMN thanks the DST, New Delhi for providing project ESS/23/ VES/006/98 that enabled him to initiate the study of subsurface sediments of Kerala. The infrastructure facilities provided by the authorities of ARI, Pune and VMFT, Thiruvananthapuram are appreciated. The facilities extended by Dr Jayasri Banerji, Officiating Director, BSIP, Lucknow, and discussion with Drs Amalav Bhattacharyya and R.R. Yadav of the same institute are duly acknowledged.

\section{REFERENCES}

Agarwal, D.P., Gupta, S.K. and Kusumgar, S., 1970: Radiocarbon dates of Quaternary samples. Current Science, 39: 219-22

Bhattacharyya, A. and Yadav, R.R., 1989: Dendroclimatic research in India. Proc. India Nat. Sci. Acad., 55: 696-701.

Chowdhury, K.A., 1964: Growth rings in Tropical trees and taxonomy. Jour. Ind. Bot. Society, 43: 334-34.

Creber, G.T., and Francis, J.E., 1999: Fossil tree-ring analysis: palaeodendrology. In: Jones T.P. and Rowe N.P. (editors) - Fossil plants and spores: Modern techniques:245-250. Geological Society, London.

Kale, V.S., Gupta A. and Singhvi A.K., 2004: Late Pleistocene-Holocene palaeohydrology of monsoon Asia. J. Geol. Soc. India, 64: 403-417.

Nair, K.M., Padmalal, D., \& Kumaran, K.P.N., in press: Quaternary geology of South Kerala Sedimentary basin - An outline. J. Geol.Soc. India.

Verheyden, A., Helle, G., Schleser, G.H., Dehairs, F., Beeckman, H. and Koedam, N., 2004: Annual cyclicity in high-resolution stable carbon and oxygen isotope ratios in the wood of the mangrove trees of Rhizophora mucronata. Plant, Cell \& Environment

For full references please consult: www.pages-igbp.org/products/newsletters/ref2005_1.html

\title{
An Upwelling Seesaw in the Atlantic Ocean: Model Results and Paleoceanographic Evidence
}

\section{Prange and M. Schulz}

DFG Research Center Ocean Margins and Dept. of Geosciences, University of Bremen, Klagenfurter Strasse, 28334 Bremen, Germany; mprange@palmod.uni-bremen.de; mschulz@palmod.uni-bremen.de

\section{Coastal Upwelling in the Atlantic Ocean}

Coastal upwelling regions are important areas of investigation for paleoclimate research because of their high-resolution sedimentary archives and their sensitivity to environmental changes. Understanding the interactions between coastal upwelling zones and climatic conditions is crucial for a proper interpretation of the sedimentary record. In the Atlantic Ocean, the two major coastal upwelling regions are located along the coasts of northwestern (Mauritanian upwelling zone) and southwestern Africa (BenguelaNamibia upwelling system). The strength of African coastal upwelling is a function of the alongshore winds, which in turn are closely tied to the trade-wind systems in both hemispheres. We analyzed the response of the major Atlan-

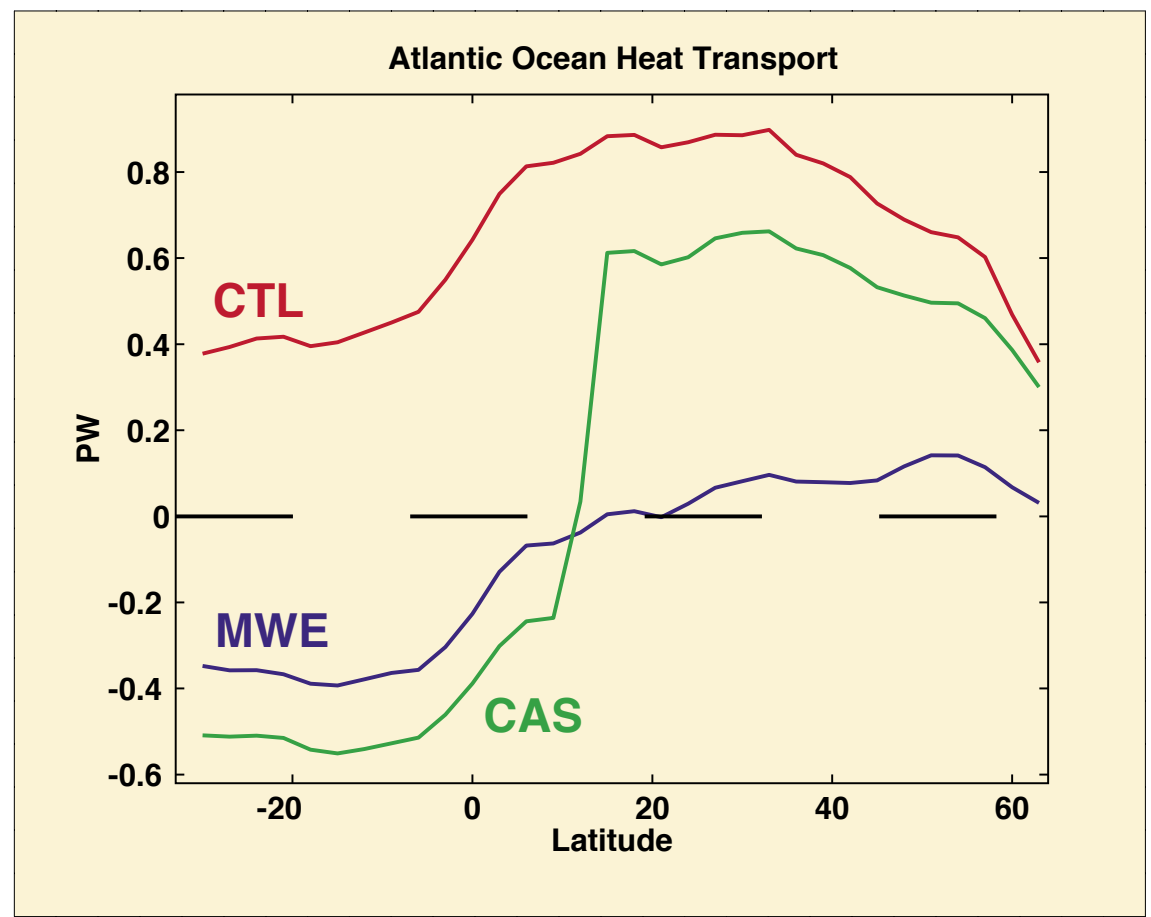

Fig. 1: Northward heat transport in the Atlantic Ocean for experiments CTL (control), MWE (meltwater event) and CAS (Central American Seaway). A reference temperature of $1.3^{\circ} \mathrm{C}$ has been used in the calculations. 


\section{Science Highlights}

\section{Modern Situation}

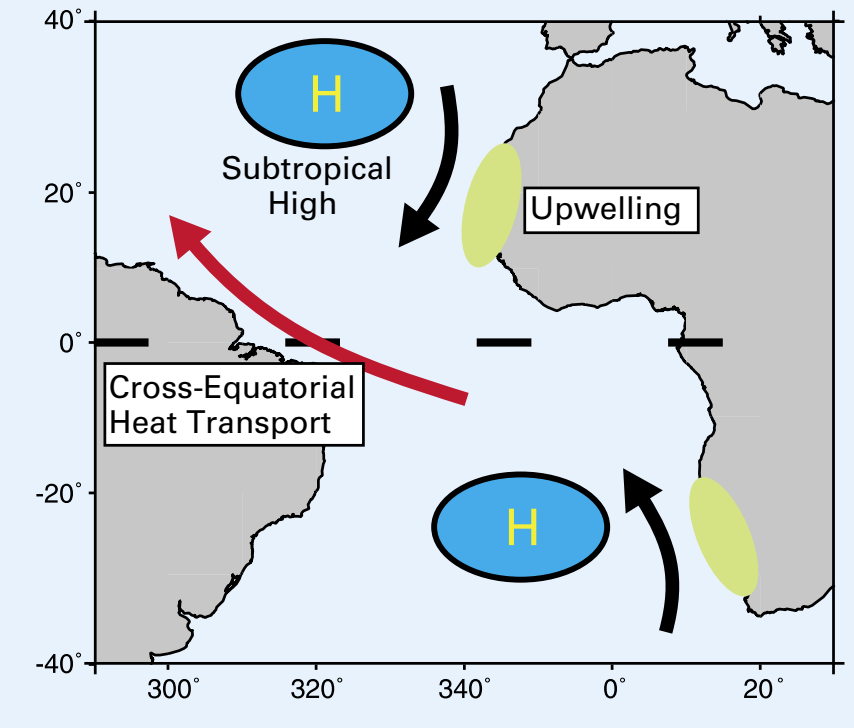

\section{Reversed Cross-Equatorial Heat Transport}

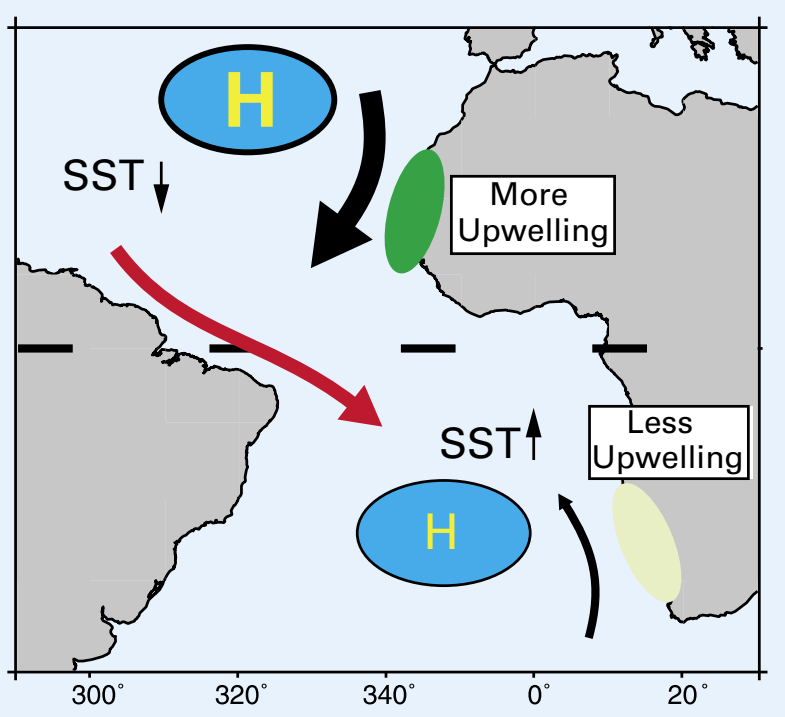

Fig. 2: Schematic of the coastal upwelling seesaw in the Atlantic Ocean. Today, the subtropical highs over the North and South Atlantic are associated with a trade-wind system that promotes upwelling along the coasts of northwestern and southwestern Africa (left panel). A reduced or reversed cross-equatorial oceanic heat transport causes sea-surface temperatures to drop in the North Atlantic and increase in the South Atlantic. The resulting effect on the atmospheric pressure system changes the trade-wind strengths, such that upwelling is intensified along the NW-African coast and weakened off SW-Africa (right panel).

tic coastal upwelling regions to shifts in large-scale oceanic heat transport (Prange and Schulz, 2004). Based on coupled climate model experiments, we suggest an antiphase behavior between the upwelling intensities off northwest and southwest Africa. This teleconnection can be described as a "coastal upwelling seesaw". The state of this upwelling seesaw is controlled by variations in the Atlantic cross-equatorial oceanic heat transport.

\section{The Coastal Upwelling-Seesaw in a Coupled Climate Model}

Substantial reorganizations of the large-scale oceanic circulation (and hence cross-equatorial heat transport) took place several times in the history of the Atlantic Ocean, induced by abrupt changes in thermohaline surface forcing (e.g., Heinrich Events of the last glacial period) or tectonic shifts (e.g., the closure of the Central American Seaway in the Pliocene). In order to study the effect of such processes on Atlantic coastal upwelling dynamics, we performed two sensitivity experiments with the coupled global atmosphereocean model ECBILT-CLIO version 3 .

The first experiment mimics a glacial meltwater event (experiment MWE): A complete shutdown of North Atlantic Deep Water formation is induced by an anomalous freshwater input to the North Atlantic between $50^{\circ} \mathrm{N}$ and $70^{\circ} \mathrm{N}$. The induced reorganization of the oceanic thermohaline circulation resembles the processes that occurred during Heinrich Events.

In the second experiment, we introduce a Central American Seaway (CAS) with a depth of $700 \mathrm{~m}$. This topographic situation is similar to the paleobathymetric conditions in the late Miocene, somewhere between 12 and 6 million years ago. The CAS gives rise to a transport of tropical water masses from the Pacific into the Atlantic Ocean. The mean total volume transport through the gateway amounts to 14 Sverdrups. Owing to this inflow of relatively fresh water masses into the Atlantic, the formation of North Atlantic Deep Water decreases by about $50 \%$ compared to a control run (CTL) with the closed Isthmus of Panama.

Both the meltwater input in experiment MWE and the bathymetric modification of experiment CAS lead to substantial changes in the Atlantic Ocean meridional heat transport (Fig. 1). Most importantly, the heat transport across the equator reverses compared to $C T L$, causing a redistribution of heat with cooling in the North Atlantic and warming in the South Atlantic. The altered seasurface temperatures influence atmosphere dynamics; cooling in the North Atlantic intensifies the northern hemispheric subtropical high. In contrast, over the South Atlantic, the subtropical highpressure cell is weakened by the oceanic warming. The resulting anomalies in wind stress affect the Atlantic coastal upwelling systems through changes in Ekman pumping; the modified trade-wind systems tend to intensify upwelling off northwest Africa, while upwelling in the Benguela-Namibia system is reduced (Fig. 2; Prange and Schulz, 2004). 


\section{Science Highlights}

Paleoceanographic Evidence for an Upwelling-Seesaw Effect During Heinrich Events

Little et al. (1997) analyzed relative abundances of the cold-water planktonic foraminifer Neogloboquadrina pachyderma (left coiling) in sediment cores from the Benguela-Namibia upwelling system over the last 140,000 years. Short periods of low abundance, indicating reduced coastal upwelling, coincide with Heinrich Events. This correlation is particularly striking for Heinrich Events 2 and 4.

For the Mauritanian upwelling zone, high-resolution proxy records for the last 35,000 years were presented by Zhao et al. (2000). A low percentage of the coccolithophorid Florisphaera profunda during Heinrich Event 2 suggests a weak surface water stratification due to enhanced upwelling intensity. Kiefer (1998) estimated primary productivity over the last glacial period from a core located southwest of the Canary Islands, about $450 \mathrm{~km}$ off the coast of northwestern Africa. Peaks in paleoproductivity coincide with Heinrich Events 2-5. A possible explanation for these peaks is that an increased amount of nutrientrich upwelling water was advected from the coast towards the core location.

\section{A Coastal Upwelling-Seesaw in the Pliocene?}

Utilizing results from Ocean Drilling Program Site 1084, situated off the coast of Namibia, Marlow et al. (2000) reconstructed the upwelling history from the early Pliocene to the late Pleistocene. Around 4 million years ago, increases in mass accumulation rates of organic carbon, diatom abundance, and the proportion of upwelling species in the diatom assemblage coincide with the final stages of the CAS closure. We hypothesize that the increase in upwelling intensity off Namibia during the Pliocene is attributable to the closure of the CAS, the resulting increase in northward oceanic heat transport (cf. Fig. 1) and the operation of the Atlantic coastal upwelling seesaw. Unfortunately, no unequivocal Pliocene reconstruction exists for the upwelling region off northwestern Africa. For an improved understanding of Pliocene climate processes, future studies should focus on upwelling proxies for the Mauritanian upwelling zone.

\section{AcKNoWledgments}

This research was funded by the Deutsche Forschungsgemeinschaft through the DFG Research Center "Ocean Margins" at the University of Bremen. More information about the ECBILT-CLIO climate model, including a list of references, is available at www.knmi.nl/onderzk/CKO/ecbiltpapers.html.

\section{REFERENCES}

Kiefer, T., 1998: Produktivität und Temperaturen im subtropischen Nordatlantik: zyklische und abrupte Veränderungen im späten Quartär, Reports, Geol.Paläont. Inst. Univ. Kiel, 90

Little, M.G., Schneider, R.R., Kroon, D., Price, B., Summerhayes, S.P., and Segl, M., 1997: Trade wind forcing of upwelling, seasonality, and Heinrich events as a response to sub-Milankovitch climate variability, Paleoceanography, 12: 568-576.

Marlow, J.R., Lange, C.B., Wefer, G. and Rosell-Mele, A., 2000: Upwelling intensification as part of the Pliocene-Pleistocene climate transition, Science, 290: 2288-2291.

Prange, M., and Schulz, M., 2004: A coastal upwelling seesaw in the Atlantic Ocean as a result of the closure of the Central American Seaway, Geophysical Research Letters, 31, L17207, doi: 10.1029/2004GL020073

Zhao, M., Eglinton, G., Haslett, S.K., Jordan, R.W. Sarnthein, M., and Zhang, Z., 2000: Marine and terrestrial biomarker records for the last 35,000 years at ODP site 658C off NW Africa, Organic Geochemistry, 31: 919-930.

\section{Call for a PAGES Initiative on "Past Regional Climate Variability"}

\section{H. WANNER}

NCCR Climate*, University of Bern, 3012 Bern, Switzerland; wanner@giub.unibe.ch

Understanding past environmental variability is a prerequisite for the understanding of future environmental change. If we intend to diagnose, for instance, past climate variability, we have to be aware that a variety of natural and anthropogenic forcing mechanisms, as well as mechanisms inducing internal variability, act together and form a "cocktail" composition that is temporally very variable. The pattern of interaction in figure 1 attempts to document this fact. The upper boxes show how the forcings, together with natural variability, jointly influence the different subsystems of the climate system. As a result of these interactions, a variety of large-scale circulation patterns, modes and regimes are generated. These modes or regimes

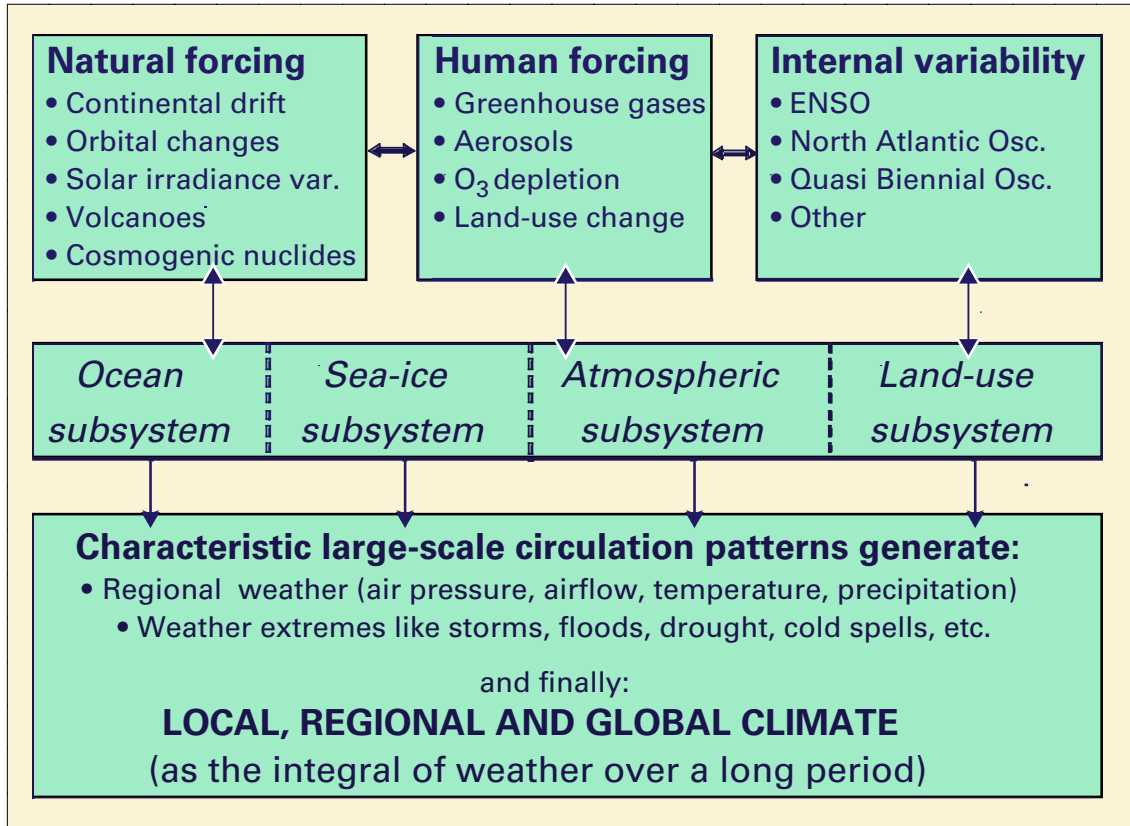

Fig. 1: Pattern of interaction demonstrating how the different natural and anthropogenic forcing factors, together with internal variability, generate local and global climate variability and change. 